\title{
LA MÁS RUIDOSA AVENTURA (QUIJOTE, I, XX)
}

\author{
José-Carlos Mainer \\ Universidad de Zaragoza
}

\begin{abstract}
The "adventure" of the batanes (fulling machine) (I, XX) proves how an ordinary event may turn into something extraordinary. In order for such thing to happen fantasy or imagination are essential, but sensorial perception is also needed, and then the narrative approaches the domain of drama. If both music and harmonic voices are significant in Don Quixote, noise, that may stand for chaos and also for thought disorder are important as well. In this chapter Don Quixote construes -thanks to his own perception, influenced by his fantasy-an adventure in which a new relationship between knight and squire is established. The knight's meditation on story-telling when he comments on Sancho's tales blends grotesque and scatological elements in an uncertain and dark atmosphere, whose explanation offers new perspectives in the interpretation of the literary contract between the two characters.
\end{abstract}

\section{DE SUCESOS Y AVENTURAS}

Quien repase con atención los títulos que Cervantes dio a los capítulos del Quijote, realizará un curso general acerca de las estrategias de umbrales y paratextos mucho más suculento del que le puede ofrecer la lectura de los Seuils que propuso Gerard Genette (1987) hace ya algunos años. Reparará, por ejemplo, en que, al lado de la inevitable palabra "aventura", que designa en treinta y ocho ocasiones, para un total de ciento veinticinco capítulos, las peripecias de los personajes, no es infrecuente la palabra "sucesos" (y equivalentes tales como "historia", "acaecimientos", "extrañas cosas", "raros sucesos"), sobre todo en la Segunda Parte.

Registro hasta quince incidencias de ese término, sin contar la omnipresencia de la flexión del verbo "suceder", aunque la mayoría sirvan para consignar "otros sucesos", en un evidente rango de acontecimientos subalternos. Parece obvio que el "suceso" es una cosa que acaece inesperada y sorprendente, inquietante e insólita, porque es una propuesta que la realidad hace a la imaginación; la "aventura" (término al que podemos sumar "trabajos" y "batalla") parece proceder, más bien, de una actividad del magín que convierte en enigma un hecho ordinario y común: molinos de viento, rebaños en marcha, cuerda de galeotes. Adviértase, por ejemplo, que la titulación del capítulo LXIX de la Segunda Parte (donde se cuenta "el más nuevo y raro suceso") anticipa el secuestro de los héroes, el descubrimiento de las fingidas honras fúnebres de Altisidora y la resurrección de la misma, culminación de las supercherías organizadas por los Duques para burla y confusión de sus invitados. Y reparará también el lector en que el capítulo LIX de la Segunda Parte anuncia un "suceso extraordinario que se puede tener por aventura" y que es precisamente la más atrevida y estupenda incursión metaliteraria de la obra: el hidalgo y su escudero oyen desde su habitación en la venta la conversación de dos caballeros, don Jerónimo y don Juan, que se aprestan a leer un capítulo del Quijote de Avellaneda, y los dos héroes y los huéspedes lectores comentan con apasionamiento la cuestión. Y es que en la Segunda Parte hay más sucesos que se truecan en aventuras, porque don Quijote ya no es el único en transitar la línea que separa la realidad de la ficción. 
¿A qué índole pertenece nuestra aventura de los batanes (Primera Parte, Capítulo XX)? Es, sin duda, aventura y por añadidura "jamás vista ni oída": pertenece de lleno a la jurisdicción calenturienta del héroe. El título juega, por supuesto, con la duplicidad semántica de "oída": habla de la expectativa que el lector tiene de "ver y oír" lo que lee (el Quijote es una invitación permanente a visualizar lo que yace en la letra), pero también nos advierte que la que sigue es una aventura ruidosa. Algo similar ocurre con los encarecimientos de la aventura de los molinos (I, VIII), que es tildada de "espantable y jamás imaginada": volveré sobre el asunto de la fantasía y la imaginación, pero ¿de quién es imaginada la aventura en nuestro caso? ¿De la incansable voluntad del hidalgo o de la capacidad de imaginar que pueda tener el lector? Esta de los batanes es además particularmente significativa entre las aventuras de un don Quijote tildado de "famoso y valeroso". Que es "famoso" lo sabe ya el lector: desde el comienzo de la novela se parte del supuesto de que se le están narrando las peripecias de un personaje que ya conoce. Que es "valeroso" lo va a averiguar al certificarse su impavidez ante los peligros... imaginarios: el ruido que generan unos batanes que golpean rítmicamente en la noche y que sume a nuestros dos héroes en la confusión y a don Quijote en la comezón irresistible de convertir una impresión en aventura.

\section{SOBRE LA FANTASÍA}

El mecanismo es, en principio, el más simple de los que preside el protocolo de las aventuras quijotescas: el trueque de una realidad irrelevante y cotidiana en una fantasía caballeresca. Y, más aún, se trata aquí de una realidad vinculada a la vida moderna, cuya cotidianeidad parece rechazar un caballero empeñado en vestir armas propias del siglo XV (aunque la práctica de justas y torneos subsistiera ampliamente en su tiempo) y en calzar conceptos propios del siglo XVI (aunque los decretos tridentinos habían levantado oleadas de desconfianza). En el capítulo VIII, los molinos de viento -construidos a semejanza de los flamencos- testimoniaban, desde hacía muy pocos años, la incipiente "industrialización" de uno de los graneros de España; los pellejos de vino en la venta (que hallaremos en el capítulo XXXV) recordaban el auge mercantil de las bodegas manchegas; los batanes de nuestra historia - como los grandes rebaños de ovejas merinas del capítulo XVIII- evocaban el esplendor, ya un tanto claudicante, de la industria lanera en el centro del país. No creo que a Cervantes, recaudador de contribuciones, le fuera indiferente el regocijo de convertir las muestras o las reliquias de una economía moderna en otros tantos objetos de confusión (y confutación) quijotesca.

Pero aquella mutación de las representaciones visuales no era, para un lector cultivado de la época, un asunto baladí, sino un problema de psicología del conocimiento harto complejo. No era lo mismo fantasía que imaginación, aunque a menudo los autores (y el propio Cervantes) las confundan: la fantasía equivale a "visio, imago rerum animo infidentium" ("visión o imagen de las cosas que se introduce en el ánimo", a partir de una impresión que proviene de la realidad); la "imaginación" es "alicuius rei conceptio et fictio" ("concepción y ficción de alguna cosa", propia del "intellectus passivus"; es decir algo más estable y elaborado que la "fantasía"), todo ello según apunta el casi coetáneo y siempre socorrido Tesoro de la lengua castellana o española, de Sebastián de Covarrubias. La gradación establecida se comprueba en el capítulo I de la Primera Parte, cuando se nos cuenta que al hidalgo "llenósele la fantasía de todo aquello que leía en los libros y 
asentósele de tal modo en la imaginación que era verdad toda aquella máquina de soñadas invenciones que leía".

En la aventura de las carretas de las Cortes de la Muerte (II, 11), el propio caballero aconseja a su escudero que "dejemos estos fantasmas y volvamos a buscar mejores y más calificadas aventuras". Y la Duquesa, bastante sabihonda y atrevida, espeta a don Quijote que su señora Dulcinea "no es en el mundo sino que es dama fantástica, que vuesa merced la engendró y parió en su entendimiento, y la pintó con todas gracias y perfecciones que quiso" (los subrayados son siempre míos, J.-C. M.). Es patente que en nuestro caballero, la imaginación tiende a ser una sucesión de fantasías que va sedimentando un comportamiento, pero su proceso de conocimiento no es sustancialmente distinto del que viven los enamorados y, en general, las gentes ardorosas. En un excelente trabajo, Guillermo Serés ha llamado la atención sobre la secuencia epistemológica que describe el soneto VIII, de Garcilaso, cuando leemos que "De aquella vista pura y excelentes / salen espirtus vivos y encendidos", que entran por los ojos del contemplador ("de tal calor movidos"), se almacenan en la memoria y, al encenderse en la ausencia de la verdadera figura de la amada, queriendo buscar de nuevo sus ojos", "revientan por salir do no hay salida" (Serés 1994: 207-236); para el caso cervantino, es imprescindible el repaso de la cuestión, trazado por José María Pozuelo Yvancos (2004: 547-560).

¿Encarecimiento lírico o lección de fisiología galénica acerca de naturaleza y la fuerza de las sensaciones imaginarias? Nunca sabremos muy bien dónde acaba una cosa y empieza la otra en una edad donde la poesía y la ciencia, el conocimiento y la belleza, no tienen todavía ámbitos tan definidos como hogaño. Y donde la locura, como es nuestro caso, puede ser un exceso de actividad mental que linda a menudo con la sabiduría y que parte de un admirable y vasto saber. Don Quijote es un loco pero un loco sistemático, que hubiera suscrito el comentario que puso Fernando de Herrera al verso 6 del soneto III del mismo Garcilaso ("pienso remedios en mi fantasía", dice allí el amante desesperado por el alejamiento): "Es la fantasía potencia natural de la ánima sensitiva, y es aquel movimiento o acción de las imágenes aparentes o de las acciones impresas; tomó nombre griego de la lumbre, como dice Aristóteles, porque el viso, que es el más aventajado y nobilísimo sentido, no se puede ejercer sin lumbre, y porque así como la lumbre o claridad, según refiere Plutarco en las opiniones de los filósofos, muestra las cosas que rodea e ilustra; así se muestra la fantasía misma" (Serés 1994).

\section{DE MÚSICAS Y DE RUIDOS}

Como bien decía la Duquesa, la fantasía pinta en nuestra conciencia y es cuestión particular el crédito que demos a sus imágenes. Don Quijote tiende a concederles todo, en la medida en que se asocian a aquel próvido almacén de sus lecturas caballerescas; pero el origen es siempre una noticia de los sentidos. Que no siempre es tan clara y distinta como debiera... Cierto es que la aventura nocturna es un recurso habitual en los libros de caballerías, pero pienso también que las horas propicias del anochecer son, muy a menudo, engendradoras de fantasías quijotescas. ¿Olvidaremos que amo y criado entran en el gozoso pero también fantástico ambiente de las bodas de Camacho en las horas del crepúsculo, las mismas en que empieza la aventura de los batanes? Y, sobre todo, ¿dejaremos de lado un eco indiscutible en la Segunda Parte, capítulo IX, cuando caballero y escudero se adentran en el pueblo de El Toboso en una noche ya avanzada ("medianoche era por filo...", como 
en el romancero), aunque "entreclara", donde las medrosas sombras nocturnas se acompañan de "ladridos de perros" y del desafinado concierto en el que "rebuznaba un jumento, gruñían puercos, mayaban gatos"? La noche y el ruido se juntan y subrayan un episodio que también va a ser de confusión. No está tan lejos aquel soneto de Lope (CXXXVII de las Rimas) que empieza "Noche, fabricadora de embelecos, / loca, imaginativa, quimerista" y que la presenta como "habitadora de celebros huecos, / mecánica, filósofa, alquimista" (las dos tripletas de adjetivos no están puestas a ojo: asocian la nocturnidad a los desvaríos del raciocinio académico y libresco, lo que daría de sí para un sabroso comentario). Copio el poema de la edición de las Rimas, en Lope de Vega, Obras poéticas, I, ed. José Manuel Blecua (1969: 105), que consigna variantes en la versión del Cancionero del Duque de Estrada.

La gnoseología cervantina construye y explica la manía fantástica de don Quijote pero también edifica un mundo narrativo en el que la visualización es la ley primera. No nos extrañará, por esto mismo, que la pauta de esa tendencia aproxime tantas veces lo imaginado a lo escénico: la novela es un gran tablado, un escenario ideal, donde las entradas y las salidas, las máquinas y los coros, parecen transitar como Pedro por su casa. Pero, como sucede en la aventura de los batanes, una escenografía no es solamente percepción visual; es también polifonía de voces humanas, placentera llegada de acordes armoniosos... o irrupción de ruidos. Nuestro capítulo XX no es el único en ese último orden de cosas: hemos citado ya la entrada en El Toboso, pero el lector tendrá presente, en el capítulo XLVI, de la Segunda Parte, el "temeroso espanto cencerril y gatuno que recibió don Quijote en el discurso de los amores de la enamorada Altisidora" y, sobre todo, unas páginas más allá, en el capítulo LIII, el "fatigado y espantoso remate que tuvo el gobierno de Sancho Panza", con "ruido de campanas y de voces", al que se añade luego "el de infinitas trompetas y atambores".

La concepción cervantina del mundo (que es, a fin de cuentas, la de su tiempo) se basa en la nostalgia de la homogeneidad de la naturaleza pero, por eso mismo, se siente fascinada por los opósitos. Existe el desorden en tanto hay orden; existe la música acordada en tanto existe el ruido desacordado. Para un humanista vulgar del siglo XVI (y eso era nuestro Cervantes), la música entraña la relación entre la armonía del mundo y la armonía del ánimo, una vieja noción pitagórica que es fácil espigar a lo largo de la novela. Las notas musicales anuncian a menudo la aventura o ilustran de antemano la calidad sugerente de un personaje que comparece. En el capítulo XXVIII de la Primera Parte, por ejemplo, don Quijote y su nutrida compañía caminan por Sierra Morena, donde oyen unos retóricos lamentos. Es un labrador que, de repente, se nos ha transformado en doncella, y la doncella en una discreta Dorotea que nos cuenta su historia de amores y engaño. Y quien, en los ratos del día que le dejaban sus labores domésticas, "los entretenía en ejercicios que son a las doncellas tan lícitos como necesarios, como son los que ofrece la aguja y la almohadilla y la rueca muchas veces, y si alguna, por recrear el ánimo estos ejercicios dejaba, me acogía al entretenimiento de leer un libro devoto o tocar una harpa, porque la experiencia me mostraba que la música compone los ánimos descompuestos y alivia los trabajos que nacen del espíritu".

Pero la afición filarmónica no es sólo asunto de una señorita de pueblo con pretensiones. También los pastores tienen alma musical. El capítulo XI de la Primera Parte nos ha presentado ya la escena de los cabreros que, en buena medida, marca la primera 
ruptura de la convención bucólica, con el fuerte olor de tasajos, la rudeza de las pieles en que se acomodan, el incómodo dornajo (una artesa, que ponen del revés) en la que hacen sentar al caballero, la basta copa de cuerno, las ácidas bellotas avellanadas y el queso, "más duro que si fuera hecho de argamasa". Don Quijote fantasea de nuevo y les endosa el discurso de la Edad de Oro, ejercicio retórico en el que no deja de alentar alguna melancolía ("Dichosa edad y siglos dichosos, aquellos a quien los antiguos pusieron el nombre de dorados..."), y la respuesta del auditorio se encarna en "un zagal muy entendido y enamorado", y que sobre todo "sabe leer y escrebir y es músico de un rabel que no hay nada más que desear". Al cual le reclaman cantar "el romance de tus amores, que te compuso el beneficiado tu tío que en el pueblo ha parecido muy bien".

Aludía, líneas atrás, a la ley de la escenificación que preside la construcción del Quijote. Descubrimos los personajes por la voz, como antes hemos visto con Dorotea en Sierra Morena. Y como sucede con el caballero del Bosque en el XII de la Segunda Parte. Don Quijote ha visto un desconocido armado que descabalga y piensa que "aventura tenemos" porque "a lo que parece templando está un laúd o vigüela" (el laúd se tañe con arco, la vihuela se puntea) y "según escupe y se desembaraza el pecho, debe prepararse para cantar algo". En la ya aludida escena de los cabreros, tras acabar de cantar el primer pastor, llega otro de la aldea con el bastimento y les narra la historia de la pastora Marcela, causa del suicidio por amor de su amante desdeñado, el estudiante Grisóstomo. Y la escena imaginaria se puebla de voces: "Aquí sospira un pastor, allí se queja otro; acullá se oyen amorosas canciones, acá desesperadas endechas". Reunidos todos en el lugar de los trágicos acontecimientos, Vivaldo, un viajero, da lectura -ya en el capítulo XIII- a la "Canción de Grisóstomo". Y como la voz y la visualización son parientes tan estrechos en el ámbito narrativo, entonces llega "la maravillosa visión" (una troquelación ésta que daría para escribir un ensayito acerca de la imaginación cervantina): "Y fue que por encima de la peña donde se cavaba la sepultura pareció la pastora Marcela, tan hermosa, que pasaba a la Fama su hermosura". Un risco, a cuyo pie hay un sepulcro y que actúa de peana de una hermosa doncella y de púlpito de su elocuencia: la composición es una suerte de atrevido altorrelieve donde encaja a las mil maravillas el más famoso discurso de la libertad pronunciado en el Quijote.

Pero también es escenografía pura (y escenografía bien sonora) la que enmarca las bodas de Camacho, a partir del capítulo XIX de la segunda parte, y si la de la sepultura de Grisóstomo y la rebelión de Marcela revisten dimensiones de tragedia, ésta parece convocar la amable fantasía de las fiestas cortesanas. A ello corresponde una de las características historias cervantinas al modo de las muñecas rusas, unas encajadas en otras, que -como más arriba recordaba- también comienza en las horas inciertas del atardecer y con un ruido que se va haciendo armonía: hay un cielo estrellado presidiendo y, al paso de los admirados recién venidos, "confusos y suaves sonidos de diversos instrumentos, como de flautas, tamborinos, salterios, albogues, panderos y sonajas, y cuando llegaron cerca vieron que los árboles de una enramada que a manos había estaban todos llenos de luminarias, a quien no ofendía el viento, que entonces no sopla sino tan manso que no tenía fuerza para mover las hojas de los árboles. Los músicos eran los regocijadores de la boda, que en diversas cuadrillas por aquel agradable sitio andaban, unos bailando y otros cantando, y otros tocando la diversidad de los referidos instrumentos" (el salterio es una suerte de clavicordio manual que se toca con púa; el albogue es la flauta de dos cañas). 
Siempre hay música de fondo, dispuesta a sorprender y cautivar nuestros oídos... No olvidemos que Cervantes nació en 1547, un momento importante en la codificación de lo que cabría llamar la música personal, la domesticada para uso del caballero y de la dama de ánimo gentil. Cundían los libros de partituras en cifra para vihuela (que estuvieron tan estrechamente asociados a la difusión de poesía de todo tipo, como señaló José Manuel Blecua en un estudio luminoso): en 1536 Luis de Milán publicó El maestro, y en 1546, Alonso Mudarra, sus Tres libros de música en cifra para vihuela, mientras que Miguel de Fuenllana dio a conocer la Orphenica Lyra en 1554 y Juan Vásquez en 1560, sus Sonetos y villancicos a cuatro y cinco voces. Pero esta música polifónica y compleja requería ejecutantes diversos y entrenados y duró muy poco. En la época del Cervantes todavía joven -digamos en el octavo decenio del siglo- las cosas estaban cambiando: se pasó de la vihuela a la guitarra (que son instrumentos parecidos, más sonora la segunda), como se trocó la polifonía por la monodia, y del punteo de las notas precisas se pasó al rasgueo típico del acompañamiento a la voz. El útil Método muy facilíssimo para aprender a tocar la guitarra, de Luis de Briceño, apareció en 1627, pero el primero de los tratados del nuevo instrumento, el de Juan Carlos Amat, tiene fecha de 1596, y de 1674 fue la memorable Instrucción de música sobre la guitarra española, de Gaspar Sanz, el más famoso de todos.

Saber tañer y cantar era signo indiscutible de elevación del ánimo, como recordaban todos los tratados de época, desde El cortesano, de Baltasar de Castiglione. Cuando Cervantes pintó en Preciosa, la gitanilla, a una falsa gitana pero que encarna una vida libre y honesta, pícara y personal, la hizo "rica de villancicos, de coplas, de seguidillas y zarabandas y de otros versos, especialmente de romances, que los cantaba con especial donaire", acompañada de unas simples sonajas y marcando a la par pasos de baile. Y don Quijote ¡cómo no! canta también. En el capítulo XLIV de la Segunda Parte, se disponía a conciliar el sueño, cuando Altisidora, acompañada de un harpa, le ha cantado un romance de amores; por eso, en el capítulo XLVI ha encargado a una doncella amiga de Altisidora que le pongan laúd en su habitación y lo usa para corresponder adecuadamente a la fineza y consolar a la dama enamorada: "Hecho esto y llegadas las once de la noche, halló don Quijote una vihuela en su aposento. Templola, abrió la reja y sintió que andaba gente en el jardín; y habiendo recorrido los trastes de la vihuela y afinádola lo mejor que supo, escupió y remondose el pecho, y luego, con una voz ronquilla aunque entonada, cantó el siguiente romance, que el mismo aquel día había compuesto: "Suelen las fuerzas de amor / sacar de quicio las almas". Pero hay todavía más... En el capítulo LXVIII, ya de vuelta a casa y tras la "cerdosa aventura", decide que, mientras Sancho se reposa, "daré rienda a mis pensamientos, y los desfogaré en un madrigalete que, sin que tú lo sepas, anoche compuse en la memoria" y "al son de sus mismos suspiros" canta una canción que tiene la amargura de la derrota que ya inunda estas páginas postreras: "Amor, cuando yo pienso / en el mal que me das terrible y fuerte / voy corriendo a la muerte / pensando así acabar mi mal inmenso". Los dos trabajos básicos sobre la música en la obra de Cervantes se escribieron casi a la vez, aunque sin ninguna relación entre sí, uno en el exilio y otro en el interior: son los de Adolfo Salazar (1948: 21-56; 1961) y el de Miguel Querol Gavaldá (1948).

\section{EL TRIUNFO DEL RUIDO}

Pero no perdamos de vista que, en otras ocasiones, el ruido y la música andan muy cercanos, en competencia cerrada. En el capítulo XXXIV (siempre en la Segunda Parte), 
los Duques han llevado de caza a sus huéspedes, Sancho les ha molido con sus refranes y, de repente, ya echándose la noche, "luego se oyeron infinitos lelilíes, al uso de moros cuando entran en las batallas, sonaron trompetas y clarines, retumbaron tambores, resonaron pífanos, casi todos a un tiempo, tan contino y tan aprisa, que no tuviera sentido el que no quedara sin él al son confuso de tantos instrumentos" (los "lelilíes" son pífanos de madera que se tocan traveseros). Y llega el diablo que anuncia, de parte de Montesinos, que va a comunicar a don Quijote como desencantar a Dulcinea. Ya se ha creado otro escenario propicio donde se empiezan a ver luces en la oscuridad y, por supuesto, un "espantoso ruido" como de guerra, que anuncia la arribada de los carros de los sabios Lirgandeo, Alquife y Arcalaús (un artificio que el lector asociaría, sin duda, al modo de representación de las fiestas sacramentales del Corpus, por cierto). Y "cedió el enfadoso ruido de sus ruedas, y luego se oyó otro, no ruido, sino un son de una suave y concertada música formado, con que Sancho se alegró y lo tuvo a buena señal y dijo a la duquesa, de quien un punto ni un paso adelante se apartaba: -Señora, donde hay música no puede haber cosa mala. -Tampoco donde hay luces y claridad- respondió la duquesa".

La contraposición de ruido y armonía, subrayada por Sancho y la señora, es uno de los pasajes más repetidos del Quijote pero conviene leerlo más allá de un tributo ocasional a las artes de Erato: viene a ser la verbalización de una concepción del mundo. ¡El ruido! Ya se ha ido viendo que podría escribirse un libro mediano sobre el ruido en el Quijote, entendido como síntoma del desorden de la realidad y de la consiguiente obnubilación del entendimiento, ya que a las dos cosas apunta. Ahora estamos en mejor sazón para entender nuestro capítulo XX de la Primera Parte, y la sutil secuencia de percepciones que presenta la aventura de los batanes, narrada con una despaciosidad reveladora de la inminencia de grandes cosas.

Se ha hecho de noche, los héroes caminan por un prado "a tiento", llevando sus cabalgaduras de la rienda, y oyen entonces un "grande ruido de agua". Porque un ruido puede ser también natural y placentero, producto de aquel "mayordomo de Dios" -la naturaleza- que tiene sus ritmos propios. Por eso, al principio, "alegroles el ruido" a caballero y escudero, y sólo se alarman luego cuando oyen unos "golpes a compás, con un cierto crujir de hierros y cadenas que, acompañados del furioso estruendo del agua, que pusieran pavor a cualquier otro corazón que no fuera el de don Quijote". La superposición del ruido natural y el ruido humano (que hace presentir oscuras historias de mazmorras y castigos) es lo que sobresalta a los protagonistas y hace que todo empiece a ser agorero. Hay un momento en que los sentimientos se superponen contradictorios, aquel en que Cervantes habla del "temeroso y manso ruido", sintagma donde conviven por un momento, en escandaloso maridaje, dos adjetivos incompatibles. Aquellas máquinas invisibles han trocado el escenario del idilio nocturno en una fantasía temerosa y lo pone de manifiesto una armoniosa secuencia verbal, resumida en una pareja de términos inequívoca: "La soledad, el sitio, la oscuridad, el ruido del agua con el susurro de las hojas, todo causaba horror y espanto". No nos extrañará que, al hilo de tan convincente descripción, se ponga a maquinar la fantasía de don Quijote: a construir la aventura en su magín con los mimbres de las percepciones contradictorias que le llegan, de modo que "acompañado de su intrépido corazón" venga a inventar aventuras "en nuestra edad de hierro para resucitar en ella la de oro" (como ha dicho ya en el discurso a los cabreros). 


\section{UNA AVENTURA NEGOCIADA}

El caballero quiere emprender la aventura, Sancho le suplica inútilmente que esperen cuando menos la luz de alba y a la postre, ata los pies de Rocinante con el cabestro de su asno. Es la primera vez, en lo que llevamos leído de la novela, en la que el escudero adopta una iniciativa que vaya más allá de la recomendación medrosa y el lamento por las previsibles consecuencias de las aventuras. Acaba de surgir un Sancho Panza antagonista, nada falto de argucias, con conciencia de su propia dignidad de personaje y decidido a llevar adelante sus propios propósitos, sin mengua -aparente, al menos- del respeto, la obediencia y hasta la admiración que debe a su señor. Y es también la primera vez en que don Quijote aceptará que a la relación caballeresca de sus sueños se superponga, sin demasiado conflicto, la más moderna relación heril de amo y criado. Una de las maravillas de la ficción cervantina es, como sabemos, la facilidad con que don Quijote transita del plano de la realidad al plano de la fantasía: en el primero, los alojamientos en las ventas se abonan en buen dinero, al par que los estropicios; se conversa amigablemente con los viajeros y amo y criado comentan las incidencias del viaje o dan suelta a sus simples ganas de hablar. Don Quijote es, por supuesto, un cumplido caballero, que practica la pedagogía con su escudero (Cervantes sabía, pero muchos lectores modernos no lo saben, que un escudero no es un criado permanente sino un caballero en periodo de formación), pero Alonso Quijano también es un excelente y paternal amo de sus servidores. Sobre esta cuestión y sus consecuencias, vale la pena ver el artículo de Anthony Close (2001: 153165).

La nueva relación se estrena con un estupendo episodio. Sancho se ofrece a entretener a don Quijote, contando cuentos hasta el amanecer, en una original versión de Sherezade manchega. Si bien se piensa, los cuentos sirven para eso, para pasar el tiempo dilatando sus dos finales: el del cuento y el del tiempo de espera. Ocurrirá muchas veces a lo largo de esta novela en la que abundan los perezosos meandros narrativos en los que unos cuentan cosas a otros, otros ofrecen sus historias al menor pretexto, nadie renuncia a un buen rato de lectura pública y hasta algunos leen la propia historia que les anda ocupando, la de Sancho y don Quijote (digamos que se nos presenta un amplio menú: el cuento, la novela autónoma, la autobiografía y hasta la difracción metaliteraria). Pero ésta de Sancho Panza en la noche de los batanes es quizá la versión más modesta del relato dentro del relato, junto con aquella otra, en los capítulos XXV-XXVII de la Segunda Parte, donde se presenta la historia del retablo de Maese Pedro que todos los parroquianos de la venta y el mismo ventero han alabado tanto. $\mathrm{Y}$ es significativo que tanto en uno como en otro caso, Cervantes somete a escrutinio la forma tradicional de contar el cuento, confrontándola directamente con una nueva y que él mismo estaba contribuyendo a inventar, el modo literario de narrar. Se confrontan lo oral y lo escrito: Cervantes sabe que toda narración oral exige un protocolo, un arranque más o menos litúrgico, un desarrollo lleno de reiteraciones, un repertorio de fórmulas ya fosilizadas y, al cabo, una participación del oyente que, si se ve defraudada, interrumpe el relato; lo escrito tiene un ritmo intelectual diferente.

Y aquella manera es lo que no tolera don Quijote, como tampoco soporta que Sancho prevarique al usar los cultismos. Para el hidalgo, que es hombre de lectura personal, no hay más texto que el literal y cuidado, el que se cuenta con probidad y exactitud, y sin repeticiones ni formulismos ridículos y consabidos. Y quizá por eso también aborrece los refranes, cristalizaciones o quizá quistes de sentido que se levantan contra la capacidad 
dialéctica del lenguaje en libertad. Repárese que la irritación de don Quijote se dispara contra el que Sancho vaya "repitiendo dos veces lo que vas diciendo [...]; dilo seguidamente y cuéntalo como hombre de entendimiento", contra el popular abuso del narrador testifical ("que parece que ahora la veo" ha dicho Sancho de un personaje) y, al cabo y sobre todo, contra el abuso de detalles adventicios y estúpidos. En los capítulos del Retablo, el caballero y el mismo maese Pedro critican también al muchacho que se meta "en curvas o transversales que para sacar una verdad en limpio menester son muchas pruebas o repruebas" y, en palabras del titiritero, "sigue tu canto llano y no te metas en contrapuntos"; poco más allá, éste mismo le pide "llaneza, muchacho", ante una digresión poética de alto bordo, y don Quijote le reclama que no haga sonar campanas en Sansueña, siendo ésta tierra de moros y por tanto, de atabales... No es posible evitar la sensación de que el escritor reclama aquí y allá los derechos de la versión escrita, culta y sintética, del relato: aquello, en fin, que suspende y entretiene a los oyentes de la Novela del curioso impertinente (Capítulos XXXII-XXXV de la Primera Parte) y que hasta merece los plácemes del cura que, si bien la reputa algo inverosímil, "en lo que toca al modo de contarle, no me descontenta". No hagamos demasiado caso, por esta vez, de que se mencionen la verosimilitud y la edificación moral como objetivos, porque lo que aquí importa (y Cervantes lo sabía) es que el porvenir del género estaba, sobre todo, en ese "modo de contarle" y, más aún, en la capacidad que su lectura personal tenía de encandilar el ánimo de quien emprende, por sí y sin cuento oral ajeno, el largo camino de la letra escrita. Al respecto, resultan muy sugerentes las observaciones de José Manuel Martín Morán (1997: 337-368), que ha tomado en cuenta la interesante monografía de Michel Moner (1989), quien comenta por extenso el episodio de Maese Pedro que traigo a colación.

Lo que no parece casual es que todo esto transcurra en un ámbito de incertidumbres físicas, entre las tinieblas de la noche y, a mayor abundamiento, con los personajes atados unos a otros: ¿se subraya así lo impreciso de una comunicación verbal aproximada y dilatoria? ¿Se quiere someter a los personajes a una divertida degradación causada por la promiscuidad de hombres y cabalgaduras? En cualquier caso, las intempestivas necesidades de Sancho Panza y su correspondiente desahogo introducen en el texto un cuento escatológico que seguramente debía ser viejo (¿quién no ha oído algún chiste -en la escuela o en el cuartel- con el mismo planteamiento?). Sobre toda la novela pesa siempre la ¿inercia? de lo farsesco, de la burla en estado puro, a menudo incompatible con el sutil entreveramiento de registros que en otros niveles se practica. Al lector, y más al lector moderno, le fastidia que las piernas de don Quijote no anden muy limpias, o que Sancho apeste, o la violencia de los mojicones, por no hablar de los habitualísimos dobles sentidos cómicos. Es un pesado tributo a la ley del género originario y, si ésta no hubiera estado presente, no hubiera sido factible el Quijote que conocemos que consiste precisamente en reventar por todas partes las costuras de lo esperable.

Por eso resulta tan espléndido lo que sucede a la salida del sol, "al aparecer distintamente las cosas", cuando los personajes reparan en los embelecos que ha forjado la noche: los agoreros ruidos de los batanes y la confusión de los cuerpos. Se ríen a gusto amo y criado, en la que quizá es no sólo la primera sino la más hermosa manifestación de humana solidaridad de todo el libro y el escudero llega a burlarse "por modo de fisga" de las altisonantes arengas de su señor. La idea es estupenda, aunque responde muy bien a la 
polifonía latente -y contradictoria- del Quijote: toda la novela es una relativización humorística de los lenguajes específicos, como hemos visto en el caso de los usos propios de la narración oral, o de los refranes, de los usos descriptivos de la narración caballeresca. Y fijémonos, por cierto, en un revelador tránsito de lenguaje que ocurre cuando Sancho abusa de la burla y recibe un par de buenos golpes de su señor: don Quijote ha roto el tratamiento de tú que venía dando a su escudero y pasa a tratarle de vos. No se engañe el lector moderno, acerca del significado de la mutación. Tratar de tú a alguien, en la lengua del siglo XVI, era todavía un cultismo latino, una fórmula prácticamente inexistente ante la universalización del "vos" (trato que se daba al extraño pero también al superior en el ámbito familiar) y los innúmeros modos en tercera persona, cuyas diferencias se marcaban por el usual "Vuesa Merced" ("voacé" en su forma vulgar), o el encomiástico "Vuesa Excelencia". Don Quijote, siempre consciente de sí, ha roto la ficción de tener un escudero y ha dado a Sancho, con todas sus consecuencias, el trato de un criado ajustado por salario.

¿No es esto un anticipo genial de uno de los secretos del libro: ese establecer la realidad literaria de las aventuras al modo de una transacción que permanentemente se pacta entre don Quijote y Sancho, entre Cide Hamete Benengeli y el autor, entre personajes y lectores? Páginas después, en la Segunda Parte, presenciaremos una negociación tan sutil como compleja: la que llevan a cabo los dos héroes, el uno empeñado en que su escudero crea lo que ha visto en la cueva de Montesinos y el otro, el atrevido Sancho, ansioso de que su señor acepte lo que dice haber atisbado, por un hueco de la venda que le tapaba los ojos, en el viaje estelar de Clavileño.

De todas las lecturas filológicas clásicas del episodio batanesco, una de las más certeras -y sospecho que olvidada- es la de Joaquín Casalduero en Sentido y forma del "Quijote" (1949). A nuestro precursor del estructuralismo crítico le perjudicaban a menudo las simplificaciones y los atajos que le llevaron a resumir en un concepto único y vagoroso ingredientes de naturaleza muy variada, pero nunca le falló el olfato para percibir ecos y síntomas de organización interna, rastros de un mundo referencial de ideas en el río de una prosa como la de Cervantes o Galdós o en las ondas enlazadas de unos versos como los de Espronceda. Sus páginas sobre los batanes empiezan con un acierto onomástico ("Noche oscura: ruido" se titula el capitulillo) y prosiguen con un reguero de adivinaciones muy felices: advierte "ruidos que son signos" y que se sitúan en el marco de una percepción que no tiene nada de romántica, percibe una "situación" que se trueca en "aventura", y una aventura donde lo que importa es la voluntad de tenerla y no el resultado, y enumera una milagrosa variedad de registros en los diferentes niveles narrativos... En resumidas cuentas, "el climax del Quijote de 1605" se halla en este capítulo por mor del "contraste entre la intención del novelista y su manera de expresarla; la presentación irónica del mundo moderno; el fondo de alegría que tiene la visión melancólica; la búsqueda de lo absoluto enraizado en lo relativo", y todo ello resuelto en "esa riqueza pictórico-musical". No ha venido a decir mucho más el presente trabajo, a fin de cuentas; lo que no sé muy bien es si tal cosa, como el resto del Quijote, es "una muestra espléndida de arte barroco" (cito por la tercera edición del libro, la de 1970: 108-114, que se anuncia "corregida y aumentada" sobre la de 1949). 
No anduvo tan buen lector Miguel de Unamuno, que siempre desdeñaba todo aquello que dependía más estrechamente de Cervantes y que sustentaba menos el espejismo de una ficción autónoma. Nuestra aventura se despacha en el capítulo XVIII de la Vida de don Quijote y Sancho, hueco donde caben los capítulos XVIII a XX de la Primera Parte. Y es que para el escritor vasco, "la cosa está bien clara" y no es otra que la prevalencia del designio de voluntad sobre las convenciones del mundo: "Para enderezar entuertos y resucitar la caballería y asentar el bien en la tierra no es menester distinguir de sones y saber cuáles son los batanes o no. Tal distinción no es cosa que toque al heroísmo". Y lo otro es sanchopancismo "que llaman ya positivismo, ya naturalismo, ya empirismo". La relación de enemigos de don Quijote es jugosa: no es, por supuesto, la del humanismo cristiano de Cervantes y su héroe sino la del intelectual de 1900, recién instalado en el retorno a la fe (o a la pugna por la fe), en la lógica de la contradicción sentimental y en un radicalismo político liberal, ya no socialista pero sí teñido de evangelismo.

Nadie leerá la Vida de don Quijote y Sancho para entender mejor a Cervantes sino para entender a Unamuno. Y es la regla de casi toda lectura, súbdita inevitable del principio de Werner Heisenberg acerca de cómo, en cierto nivel corpuscular, la propia observación modifica lo observado... A despecho del cual, algunas interpretaciones literarias nos ayudan a entender un poco mejor nuestro texto, siquiera sea porque aciertan a superponerse con exactitud sobre algunos perfiles que nos habían pasado inadvertidos. Es el caso eminente de Jorge Guillén que, por dos veces, se acercó en su poesía a sendos episodios del Quijote y en ambos casos a momentos que tienen que ver con la discordancia, el ruido y la incertidumbre que desasosiega: en Cántico, la sección 4, "Aquí mismo", glosa nuestro episodio de los batanes en el poema "Noche del caballero"; en Clamor, el libro A la altura de las circunstancias tiene como segunda parte otra extensa composición, "Dimisión de Sancho", que glosa la salida del escudero de su fallida gobernación de la Ínsula Barataria.

"Noche del caballero" es, sin duda y antes que otra cosa, un poema de Guillén y por añadidura un poema de Cántico, tocado del ánimo y propósito del libro que subtituló "Fe de vida". Por eso, se dedica tanto y demorado espacio a la descripción del ruido, síntoma de un mundo natural que funciona incansable, que late vivo y autónomo, preciso y por lo tanto hermoso, aunque sus disonancias puedan inquietarnos. Pero los batanes se introducen muy subrepticiamente en el poema, inciertos casi (“¿Huesos o hierros sufren o rechinan?”), como una agresión que concita en el poeta palabras con -casi ingenua- expresividad de exorcismos cacofónicos ("vestiglos", "tentáculos que pérfidos, retráctiles", “cruja y recruja por su laberinto", "puja y cruja en su estrépito el endriago"). Pero nada puede ser más guilleniano que la situación del caballero que, como todo ser consciente de este mundo, busca conocer y saber. Ambos movimientos del ánimo son la respuesta a un universo de incitaciones fervorosas (sobre el poema puede verse también la lectura de Elizabeth Matthews 1998, 1.021-1.033). Por eso, "todo está preparado" (por la naturaleza) "para guardar a quien está en su centro / Ve las tinieblas, oye las llamadas" y sabrá, en suma, entender lo inseparable de ese binomio que el poeta ha agrupado en un solo verso revelador: "!Hermosura, peligro!". Los "contratiempo, destiempo, discordancia" que han surgido en la armonía que crean, con tanto amor, la noche y sus rumores, "lo atajará quien vela". Y el vigilante encarna el honor de la humanidad; la aventura es su lema: "Cúmplase, necesaria, la aventura, / Triunfe la tentación, / Realidad para el héroe". Mundo y vigía se 
contemplan y ya son, en el fondo, lo mismo: “Agua, más agua, siempre sucediéndose" y "la vocación de un hombre más que hombre". Uno y otro son insistencia en el Ser.

\section{REFERENCIAS BIBLIOGRÁFICAS}

Fuera ocioso e impertinente que el trabajo de un cervantista de ocasión, como es el presente, viniera acribillado de notas bibliográficas y de confert. Me limito a señalar las referencias imprescindibles de lo que se cita (o se maneja) y, en un par de ocasiones, recomiendo algún estudio señero y reciente. Las numerosas citas del Quijote se hacen indicando Parte y Capítulo, todas teniendo a la vista el texto de la edición de Galaxia Gutenberg, Círculo de Lectores y Centro para la Edición de Clásicos Españoles (con la participación de la Sociedad Estatal de Conmemoraciones Culturales), llamada "Edición del Instituto Cervantes 1605-2005", dirigida por Francisco Rico (con la colaboración de Joaquín Forradellas), impresa en Barcelona, 2004, en 2 volúmenes.

CASALDUERO, Joaquín, Sentido y forma del “Quijote”, Madrid, Ediciones Ínsula, 1970.

CLOSE, Anthony, "¿Cómo se debe remunerar a un escudero, a salario o a merced?: La cuestión del realismo del Quijote", en Silva. Studia Philologica in honorem Isaías Lerner, eds. Isabel Lozano-Renieblas y Juan Carlos Mercado, Madrid, Castalia, 2001.

GENETTE, Gérard, Seuils, Paris, Seuil, 1987.

MARTÍN MORÁN, José Manuel, "Don Quijote en la encrucijada: oralidad/escritura", Nueva Revista de Filología Hispánica, XLV, 2 (1997).

MATTHEWS, Elizabeth, "Heroic Vocation: Cervantes, Guillén and Noche del caballero", Modern Language Review, 93, 4 (1998).

MONER, Michel, Cervantes conteur. Écrits et paroles, Madrid, Casa de Velázquez, 1989.

POZUELO YVANCOS, José María, "Los conceptos de Fantasía e Imaginación en Cervantes", en Largo mundo alumiado. Estudos em homenagem a Vitor Aguiar e Silva, II, ed. Carlos Mendez Sousa y Rita Patricio, Braga, Universidade do Minho, 2004.

QUEROL GAVAldÁ, Miguel, La música en las obras de Cervantes, Barcelona, Comtalia, 1948.

SALAZAR, Adolfo, "Música, instrumentos y danzas en las obras de Cervantes", Nueva Revista de Filología Hispánica, II (1948), pp. 21-56, reimpreso en el libro La música en Cervantes y otros ensayos, Madrid, Ínsula, 1961.

SERÉS, Guillermo, "El concepto de fantasía desde la estética clásica a la dieciochesca", Anales de Literatura española, 10 (1994).

VEGA, Lope de, Rimas, en Obras poéticas, I, ed. José Manuel Blecua, Barcelona, Planeta, 1969. 